\author{
МОТИВАЦІЯ ВИВЧЕННЯ ОСВІТНІХ КОМПОНЕНТІВ \\ «БЕЗПЕКА ЖИТТЄДІЯЛЬНОСТ|» Й «ОСНОВИ ОХОРОНИ ПРАЦІ» \\ В ЗАКЛАДАХ ВИЩОЇ ОСВІТИ \\ MOTIVATION FOR STUDYING EDUCATIONAL COMPONENTS \\ "LIFE SAFETY" AND "FUNDAMENTALS OF OCCUPATIONAL HEALTH \\ AND SAFETY" IN HIGHER EDUCATION INSTITUTIONS
}

Удк 378.016:614.8331.45

DOI https://doi.org/10.32843/2663$6085 / 2021 / 35.12$

\section{Білосевич І.А.,}

канд. пед. наук, доцент,

доцент кафедри теорії і методики

трудового навчання та технологій кременецької обласної

гуманітарно-педагогічної академії імені Тараса Шевченка

\section{Омельчук О.В.,}

канд. пед. наук, доцент,

доцент кафедри теорії і методики трудового навчання та технологій Кременецької обласної

гуманітарно-педагогічної академії імені Тараса Шевченка

\author{
Олексюк М.П., \\ канд. пед. наук, \\ доцент кафедри теорії і методики \\ трудового навчання та технологій \\ Кременецької обласної \\ гуманітарно-педагогічної академії \\ імені Тараса Шевченка \\ Ємець О.П., \\ старший викладач кафедри теорії i \\ методики трудового навчання \\ та технологій \\ Кременецької обласної \\ гуманітарно-педагогічної академії \\ імені Тараса Шевченка
}

У статті окреслено важливість викладання освітніх компонентів «Безпека життєдіяльності» й «Основи охорони праці» в закладах вищої освіти (ЗВО). Визначено зв'язок із дисциплінами загальної підготовки, нормативною базою у сфері безпеки життя й діяльності людини, яка керує на законодавчому рівні актуальністю реалізації освітніх компонентів $і$ їх призначенням. Порушено типові актуальні проблеми освітньокомпонентної реалізації та проаналізовано фактори, що сприятимуть покращенню вивчення матеріалу, мотивацію й підходи до методики викладання. Розглянуто способи вдосконалення методів і форм викладання та запропоновано підхід до вивчення здобувачами курсу «Безпека життєдіяльності» й «Основи охорони праці». Висвітлено курс освітніх компонентів як обсяг освітніх знань, який синтезує теоретичну i практичну інсрормацію щодо захисту людини від небезпечних і шкідливих фракторів у різних сфрерах діяльності, забезпечення безпеки і здоров'я.

Указані освітні компоненти мають чітку прив'язку до загальних і фрахових компетентностей у розрізі освітніх програм різних спеціальностей. Тому наголошено на логічному відображенні засад дисциплін «Безпека життєдіяльності» $\breve{~ « О с н о в и ~}$ охорони праці» при фрормуванні програмних результатів навчання відповідних освітніх програм, адже безпека людини, яка формується як фрахівець, і безпека тих, хто $\epsilon$ орасилітатором освітнього процесу, - невід'ємний складник їі життєдіяльності. Також деталізовано структуру викладання освітніх компонентів задля усвідомлення в подальшому значення ризику виникнення небезпек у побутовому та професійному середовищах. Особливу увагу приділено методам якісного викладання освітніх компонентів. Охарактеризовано їх роль в освітньому прочесі. У цьому плані вказано на наявність законодавчого поля щодо вирішення безпеки.

Ключові слова: безпека життєдіяльності, охорона праці, освітній компонент, компетентність, заклад вищої освіти, профе- сійна діяльність, здоров'я людини, працездатність, продуктивність праці.

The importance of teaching the educational components "Life Safety" and "Fundamentals of Occupational Safety" in higher education institutions (HEIs) is outlined. The connection with the disciplines of general training, the regulatory framework in the field of safety of life and human activity, which manages at the legislative level the relevance of the implementation of educational components and their purpose.

Typical topical issues of educational-component implementation are raised and factors that will help to improve the study of material, motivation and approaches to teaching methods are analyzed. The ways of improving the methods and forms of teaching are considered and the approach to studying by students of the course "Life Safety" and "Fundamentals of labor protection" is offered. The course of educational components is covered as a volume of educational knowledge, which synthesizes theoretical and practical information on human protection from dangerous and harmful factors in various fields of activity, safety and health.

These educational components have a clear link to general and professional competencies in terms of educational programs in various specialties. Therefore, the emphasis is on the logical reflection of the principles of the disciplines "Safety of life" and "Fundamentals of labor protection" in the formation of program learning outcomes of relevant educational programs. After all, the safety of a person who is formed as a specialist, and the safety of those who are the facilitators of the educational process - an integral part of their lives. The structure of teaching educational components is also detailed in order to further understand the importance of the risk of dangers in domestic and professional environments. Particular attention is paid to methods of quality teaching of educational components. Their role in the educational process is described. This plan indicates the existence of a legislative framework for addressing security.

Key words: life safety, labor protection, educational component, competence, institution of higher education, professional activity, human health, working capacity, labor productivity.
Постановка проблеми в загальному вигляді. у державних освітніх стандартах або документах, якими керуються при фрормуванні загальних, фахових компетентностей і програмних результатів навчання освітніх програм усіх напрямів указано, що при ознайомленні з дисциплінами «Безпека життєдіяльності» й «Основи охорони праці» здобувачі вищої освіти повинні опанувати такими компетентностями, як «здатність фрормувати бажання дотримуватися здорового способу життя та усвідомлення ролі навколишнього середовища для життя і здоров'я людини», «оперування методами захисту персоналу і населення від наслідків аварій та катастрофр» тощо. Тобто практично всі 
спеціальності при формуванні освітніх програм потребують використання складників, пов'язаних із безпекою.

Освітні компоненти «Безпека життєдіяльності» й «Основи охорони праці» $€$ дисциплінами, що включаються в навчальні плани як нормативні або вибіркові. Безпека життєдіяльності як галузь наукових знань розглядає проблеми здоров'я i безпеки людини в різних середовищах, виявляє небезпечні та шкідливі фрактори, пропонує фрорми й методи захисту шляхом зниження їх допустимих значень, розробляє способи локалізації чи ліквідації наслідків таких ситуацій.

Освітні компоненти «Безпека життєдіяльності» й «Основи охорони праці» займають важливу нішу в структурно-логічній схемі підготовки за рівнем «бакалавр», оскільки є дисциплінами, які використовують досягнення та методи фрундаментальних і прикладних наук з біології, фрізики, хімії, ергономіки, соціології, психології, екології, економіки, менеджменту тощо й дають змогу фрахівцю реалізувати завдання, пов'язані з обраною професією та врахуванням небезпек, які провокують ситуації надзвичайного характеру й наслідки їх реалізації. Мета вивчення вказаних дисциплін полягає в набутті здобувачем вищої освіти компетентностей, необхідних для реалізації профресійної діяльності за обраною спеціальністю з врахуванням небезпек і їх чинників, які можуть призвести до небажаних наслідків на об'єктах господарювання, а також усвідомлення відповідальності за особисту й колективну безпеку.

Завданням вивчення цих дисциплін є освоєння знань, умінь і навичок вирішення професійних завдань з урахуванням галузевих вимог щодо реалізації безпеки працюючих, захисту людей під час надзвичайних ситуацій і формування рівня свідомості щодо особистої відповідальності за рівень безпеки й охорони праці на об'єктах галузі, техногенних і культурних цінностей у рамках обґрунтовано прийнятних вимог щодо рівня допустимого ризикового балансу [2].

Це зумовлюється тим, що на сучасному етапі розвитку суспільства й науки набуває актуальності проблема збереження безпечної життєдіяльності в умовах реальних ризиків, що здатні дисгармонізувати як професійний, так і загальносуспільний складник життя й діяльності людини та становлення духовного світу особистості. У суспільстві, що трансорормується, відбувається суттєва перебудова системи життєвих орієнтацій, у тому числі пов'язаних зі збереженням безпеки. Для підвищення життєвої орієнтації за відповідною шкалою необхідна їі актуалізація у свідомості більшості представників людства. Особливо актуальними ці проблеми є серед студентської молоді, адже умови іiі життєдіяльності ускладнюються суспільною нестабільністю, духовно-моральною руйнацією, послабленням регулятивної ролі чинників безпеки.
Засвоївши дисципліни «Безпека життєдіяльності» й «Основи охорони праці», здобувачі повинні володіти сукупністю загальних і профресійних компетентностей щодо безпечної життєдіяльності й охорони праці відповідно до спеціальностей для реалізації професійних завдань, які пов'язані 3 гарантуванням безпеки життя і здоров'я працюючих на об'єктах господарювання під час виникнення та протікання небезпеки.

Аналіз останніх досліджень і публікацій. Рефрормування системи вищої освіти, прийняття Закону України «Про освіту» та інших, не менш важливих документів пропонують нові освітні умови. У 2014 році Кабінет Міністрів України скасував Наказ МОН та МНC «Про організацію та вдосконалення навчання з питань охорони праці, безпеки життєдіяльності та цивільного захисту у вищих навчальних закладах України» (2010р.). Та важливість, потреба здобувачів вищої освіти ознайомитися із засадами й нормами безпечної життєдіяльності залишаються. Основні дослідження та публікації, у яких аналізується ця проблема, слугують демонстрацією цього. У працях наукових дослідників з безпеки життєдіяльності й охорони праці зустрічаємо намагання висвітлити реорормування освіти в галузях вище зазначених освітніх компонентів і їх викладання у ЗВО України. Питання вивчення здобувачами цих дисциплін порушували І. Науменко, Л. Коваль, М. Лукашевич, І. Мигович, В. Поліщук, В. Бєгун та інші.

Виділення не вирішених раніше частин загальної проблеми. Дослідження у сорері життєдіяльності різних країн показують, що причиною передусім надзвичайних ситуацій техногенного й природного характеру $€$ недостатня фраховість оператора, який здійснює менеджмент у попередженні небезпечних ситуацій і локалізації наслідків, необізнаність населення правильно діяти в умовах надзвичайних ситуацій. Це й спонукало до написання статті.

Мета статті - висвітлити нагальну потребу й важливість викладання освітніх компонентів «Безпека життєдіяльності» та «Основи охорони праці» в закладах вищої освіти, деталізувати структуру викладання цих освітніх компонентів.

Виклад основного матеріалу. Кризові ситуації в сучасних складних умовах освітнього середовища, зокрема, для вчителів, педагогів, фрахівців спеціальної освіти, соціальних працівників пропагують усвідомлення необхідності вивчення загальноакадемічних курсів «Безпека життєдіяльності» й «Основи охорони праці» майбутнім фрахівцем освіти, що надасть у подальшому житті можливість знизити ризик небезпек у побутовому та професійному середовищах. У регулюванні міжособистісних відносин у будь-якій галузі роль відіграє держава. Тому питання охорони праці в організації чи на підприємстві, безпеки побу- 
тової тощо закріплені на законодавчому рівні: закони України «Про захист населення і територій від надзвичайних ситуацій техногенного та природного характеру» (2000р.); «Про внесення змін до Закону України «Про охорону праці» (2002 р.); «Про правовий режим надзвичайного стану» (2000р.); Концепція освіти 3 напрямку «Безпека життя і діяльності людини» (2001р.); а також навчальні програми освітніх компонентів «Безпека життєдіяльності» й «Основи охорони праці» для закладів вищої освіти 1998 р. [2].

Результати статистики говорять про те, що дві третини нещасних випадків та аварій на виробництві стаються 3 організаційних причин і тільки 14\% - 3 технічних, 13\% - 3 психофрізіологічних. Тому умови сучасного життя пропонують усвідомити, як правильно поводитися за умов будь-якої небезпечної ситуації. Безпека життєдіяльності галузь наукових знань, що вивчає потребу безпечного перебування особистості в навколишньому середовищі під час різних видів діяльності. Ця сорера $€$ інтегрованою й екстраполюється в дисципліну. Охорона ж праці розглядає людину, яка перебуває на виробництві, у надзвичайних ситуаціях, а безпека життєдіяльності - у всіх життєвих обставинах [6]. Увесь спектр активності людини утворює поняття діяльності. Саме остання й вирізняє людину від інших істот, вона є специфічною людською фрормою активності, необхідною умовою існування людського суспільства [2]. Форми діяльності різноманітні, охоплюють практичні, соціальні, інтелектуальні та духовні процеси, які відбуваються в побутовій сфері, громадській, культурній, виробничій та інших сорерах життєвої діяльності особистості [6].

Захищеність від небезпеки під час повсякденної та профресійної діяльності є однією зі сталих потреб людини. Людина розуміє таку захищеність як уникнення ситуації небезпеки та дії вражаючого фрактора, а в умовах її виникнення - результативно вмикати механізм протидії. Стан захищеності людини від шкідливого чи небезпечного вражаючого фрактора варто розглядати як наслідок її психофрізіологічної, соціальної й професійної якостей, біологічної здатності організму до регуляції та відновлення. Потрібно розглядати френомен індивідуальності не як властивість, яку отримують від народження, а як систему можливостей, яка розвивається та змінюється й має безпосередній вплив на захист особистості від можливих небезпек у побуті та на виробництві [3].

У контексті освітніх компонентів безпеки, про які йде мова в статті, розглядаємо три основні фрактори (згідно з психологічними рекомендаціями), що провокують травматизм:

- науково-технічний прогрес, стрімке зростання науки й техніки просувається швидше, ніж розвивається ступінь захищеності;
- ціна помилки людини, відповідно, зростає;

- має місце момент адаптації людини як біологічного організму до присутності небезпеки. Людина звикає.

Установлення безпеки є мотивуючим критерієм для її досягнення. Мова йде про психологічний стан працівника та роботодавця. Його можна вважати належним, коли він озброєний відповідним інструментом для захисту:

- якісним рівнем навчання;

- відповідними знаннями щодо небезпек і їх причин, фракторів, обставин, умов протікання та наслідків;

- запобігання, локалізації та профілактики;

- умінням будувати моделі виходу з кризових ситуацій.

Освітній компонент «Безпека життєдіяльності» має призначення: усвідомлення того, що людина як головна цінність суспільства заслуговує на увагу, виховання гуманного, свідомого ставлення до питань особистої безпеки та безпеки оточуючих у різних сорерах людських взаємин; фрормування навичок ідентифрікації небезпечних і шкідливих вражаючих чинників і створення сприятливих умов для життєдіяльності людей на відповідній території; контролювати проектування техніки й технологічних процесів згідно з вимогами сьогодення екології з урахуванням стійкості фрункціонування об'єктів господарювання та технічних систем; прогнозування можливих умов і прийняття виважених рішень під час надзвичайних ситуацій щодо захисту населення та персоналу від можливих негативних наслідків; забезпечення якісного оволодіння новим стереотипом поведінки людини для гідного існування в нових умовах, які диктує суспільство [6].

Мета засвоєння курсу «Безпека життєдіяльності» в закладі вищої освіти - усвідомлення та пропагування культури людини щодо її безпеки, моральних цінностей, поглядів, поведінки; забезпечення відповідного стану захищеності особи завдяки наявності необхідних знань і вмінь адекватної реакції на надзвичайні ситуації природного, техногенного, соціально-політичного характеру; створення правильної моделі виходу з кризових ситуацій, мотивація безпечної поведінки в різних середовищах перебування.

Засвоївши дисципліну «Безпека життєдіяльності», здобувачі повинні володіти сукупністю загальнокультурних і професійних компетентностей з питань безпеки життєдіяльності у відповідних напрямах підготовки для вирішення професійних завдань, пов'язаних із гарантуванням збереження життя та здоров'я персоналу в умовах небезпечних і надзвичайних ситуацій.

Програма 3 дисципліни «Безпека життєдіяльності» складається 3 таких модулів: Змістовий модуль 1 «Основи безпеки життєдіяльності 
людини»; Змістовий модуль 2 «Заходи щодо захисту життя людини».

Змістовий модуль 1 «Основи безпеки життєдіяльності людини» передбачає вивчення таких тем: Тема 1. Категорійно-понятійний апарат з безпеки життєдіяльності, таксономія небезпек. Ризик як кількісна оцінка небезпек. Тема 2. Природні загрози та характер їх проявів і дії на людей, тварин, рослин, об'єкти економіки. Тема 3. Техногенні небезпеки та їх наслідки. Тема 4. Соціально-політичні небезпеки, їх види та характеристики. Соціальні та психологічні фрактори ризику. Поведінкові реакції населення в надзвичайних ситуаціях.

Змістовий модуль 2 «Заходи щодо захисту життя людини» передбачає вивчення таких тем: Тема 1. Застосування ризик орієнтованого підходу для побудови імовірнісних структурно-логічних моделей виникнення та розвитку надзвичайних ситуацій. Тема 2. Основні принципи і положення захисту населення і територій у разі надзвичайних ситуацій. Тема 3. Управління силами та засобами об'єктів господарювання під час надзвичайних ситуацій. Тема 4. Культура здоров'я людини. Тема 5. Загальні принципи надання першої долікарської допомоги постраждалим. Тема 6. Пожежна безпека. Засоби пожежогасіння.

Логічним наступництвом у циклі освітніх компонентів, розпочатих «Безпекою життєдіяльності» $є$ «Основи охорони праці». Вивчення здобувачами цієї нормативної дисципліни у ЗВО України передбачає Конституція України (оскільки забезпечення життя та здоров'я особистості є обов'язком держави, адже людина та її здоров'я є найбільшою цінністю в житті). Цього вимагає Концепція ООН «Про сталий людський розвиток». Низка Законів України теж говорять про це («Про охорону праці», «Про охорону здоров'я», «Про цивільну оборону», «Про захист населення і територій в надзвичайних ситуаціях техногенного та природного характеру» тощо).

Програма з дисципліни «Основи охорони праці» складається 3 таких модулів: Змістовий модуль 1 «Теоретико-методологічні засади охорони праці»; Змістовий модуль 2 «Спеціальні розділи охорони праці в галузі».

Змістовий модуль 1 «Теоретико-методологічні засади охорони праці» передбачає вивчення таких тем: Тема 1. Міжнародні норми в галузі охорони праці. Тема 2. Основні законодавчі та нормативноправові акти України з охорони праці в галузі. Державний нагляд і громадський контроль за станом охорони праці. Тема 3. Система управління охороною праці в організації. Тема 4. Аналіз умов праці у галузі за показниками шкідливості та небезпечності чинників виробничого середовища, важкості та напруженості трудового процесу. Загальні вимоги безпеки в галузі.

Змістовий модуль 2 «Спеціальні розділи охорони праці в галузі» передбачає вивчення таких тем: Тема 5. Атестація робочих місць за умовами праці. Навчання з питань охорони праці в установах галузі освіти та організаціях невиробничої сорери. Тема 6. Травматизм і професійні захворювання в галузі. Розслідування нещасних випадків. Соціальне страхування від нещасного випадку та професійного захворювання на виробництві. Тема 7. Загальні вимоги виробничої безпеки. Тема 8. Основні заходи пожежної профрілактики на галузевих об'єктах.

Сучасна підготовка фрахівця дає особистості загальні знання, не забезпечує вміння використовувати такі знання в діяльності професійній. Реалії практики показують, що багатьом студентам бракує чіткої сорормованості позиції, вони не орієнтуються в складних умовах сьогодення, не можуть дати належної позитивної відповіді. Отже, на заняттях слід варто ставити умови для належного виконання здобувачами завдань свідомого вибору, щоб вони добре уявляли небезпечні чинники, могли навести власні приклади, демонстрували ситуації з безпеки життєдіяльності, використовували набуті раніше знання на практиці. Вагомі можливості для розвитку думки дасть самостійне мислення, яке супроводжує самостійну роботу. Ця фрорма навчальної діяльності чітко відображена навчальним планом освітньої програми. Метою самостійної роботи здобувачів вищої освіти є підготовка компетентного фрахівця зі сорормованими вміннями й навичками відтворення власних творчих задумів та ідей. Такий фрахівець прагнутиме досягти грамотної передачі форм, але відсутність нових знань, необхідного досвіду, інтелектуальних якостей і творчого мислення зумовлює певні труднощі. Щоб активізувати пізнавальну діяльність студентів під час аудиторних занять, варто використовувати такі методи навчання: наочні (екскурсія на виробництво з подальшим аналізом спостережень й обговоренням небезпечних чинників для людини); відтворювальні (аналіз конкретних ситуацій дійсності, розв'язування навчальних і виробничих небезпечних ситуацій, під час яких здобувачі самостійно завдяки пошуку різних варіантів шукають виходи з кризових ситуацій, будують поведінкові моделі, а також перевіряється правильність результатів відповідно до обговорення поставленого завдання або ситуації з виходом з кризи) [4]; практичні (за допомогою розгляду різних проблем повсякденної дійсності з безпеки життєдіяльності, побудова дерева помилок) [1]. Навчальний матеріал подається студентам у вигляді проблеми, знання здобуваються в результаті практичної роботи. Під час виправлення помилок їм потрібно дізнатися про результати своїх дій, дати оцінку власній роботі. За час розв'язування нестандартних завдань, де немає загальних положень, у студента виникає інтерес до дисципліни, яку він вивчає [6]. Застосування різноманітних фрорм впливає на активізацію (активність, розвиток мислення), дає можливість 
розуміти здобувачам момент важливості й наслідки небезпек, уміння пристосуватися до швидкозмінних умов, з успіхом вирішувати проблему, розвиває здатність, уміння відстояти власну позицію. Здобувач набуває практичних навичок і вмінь.

Розкриємо особливості засвоєння освітніх компонентів «Безпека життєдіяльності» й «Основи охорони праці» майбутніми вчителями трудового навчання та технологій.

Варто відзначити, що створення безпечних умов освітнього процесу не вичерпує повною мірою діяльність учителя трудового навчання та технологій в напрямі охорони праці та безпеки життєдіяльності.

Роль учителя трудового навчання та технологій зазнала значної переоцінки. Це пояснюється соціальним замовленням, вимогою якого $€$ фрормування нової сучасної генерації в суспільстві. При таких умовах технологічно-охоронний складник не забезпечує необхідну підготовку молоді до життя в сучасному світі. Сучасний учитель трудового навчання та технологій повинен забезпечити формування в школярів навичок безпечного використання технологічного обладнання, засвоєння цінності власного життя і працездатності. Такий стан наведених проблем вимагає відповідної підготовки майбутніх учителів трудового навчання та технологій до професійно-педагогічного складника в галузі засвоєння освітніх компонентів «Безпека життєдіяльності» й «Основи охорони праці».

Для цього в освітньо-професійних програмах підготовки «Середня освіта (Трудове навчання та технології)» передбачено фрормування фрахової компетентності: здатність дотримуватися вимог з безпеки праці, протипожежної безпеки, захисту довкілля.

Також в освітньо-професійних програмах підготовки «Середня освіта (Трудове навчання та технології)» передбачено формування програмних результатів навчання: знати основні положення нормативно-правових актів з безпеки життєдіяльності в професійній діяльності; уміти планувати заходи з профілактики виробничого травматизму і професійної захворюваності, аналізувати та усувати причини нещасних випадків; знати й дотримуватися правил безпечної експлуатації інструментів і технологічного обладнання, вимог до охорони праці, протипожежної безпеки та захисту довкілля, уміти забезпечувати їх дотримання учнями

Забезпечити фрормування компетенцій збереження здоров'я і працездатності учнів у закладах загальної середньої освіти дає змогу вивчення курсу «Основи охорони праці» й «Безпека життєдіяльності», тому цим напрямом підготовки майбутнього вчителя трудового навчання та технологій необхідно приділяти велику увагу.

Сучасний стан вивчення «Безпека життєдіяльності» й «Основи охорони праці» майбутніми фахівцями технологічної освіти характеризується невідповідністю змісту навчання вимогами до їхніх майбутніх професійно-трудових обов'язків, а також застосуванням застарілих недосконалих методів навчання цих курсів. Як відомо, традиційна система організації освітнього процесу в закладах вищої освіти має, як правило, лекційно-практичний (лабораторний) характер. Основою такої системи є отримання теоретичного матеріалу на лекціях і детальне його засвоєння на лабораторних і практичних заняттях. Згідно з термінологією, практичне заняття - це фрорма організації деталізації, розширення, аналізу, поглиблення, закріплення, застосування й контролю за засвоєнням отриманої навчальної інформації (на лекції й у ході самостійної роботи) під керівництвом викладача закладу вищої освіти. У більшості випадків сучасні умови проведення практичних робіт зводяться до глибшого відтворення теоретичного матеріалу 3 лекції. 3 огляду на важливість вивчення «Безпека життєдіяльності» й «Основи охорони праці» вчителя технологій, практичні заняття 3 охорони праці не можуть ґрунтуватися на ретрансляційних підходах. Бездумне вивчення теоретичного матеріалу, утрата зв'язку з вимогами до професійних обов'язків учителя трудового навчання та технологій не допускаються. Ми вважаємо, що доцільно й необхідно проводити заняття 3 «Основ охорони праці» та «Безпеки життєдіяльності», використовуючи методи навчання, що дають змогу найбільш точно відтворювати умови майбутньої професійно-педагогічної діяльності педагога.

Так, застосування методу кейсів у навчанні «Основ охорони праці» та «Безпеки життєдіяльності» майбутніх учителів трудового навчання та технологій дає змогу:

- підвищити пізнавальний інтерес до курсу, що вивчається;

- поліпшити розуміння професійно-охоронної діяльності;

- забезпечує розвиток креативних, інноваційних, дослідницьких, комунікативних і творчих навичок прийняття важливих рішень.

Так, наприклад, при вивченні матеріалу щодо забезпечення параметрів мікроклімату в навчально-виробничому приміщенні майбутньому вчителю трудового навчання та технологій дозволяється проаналізувати повністю порядок проведення цього заходу. При цьому важливою особливістю $€$ неповна інфрормація з наведеного питання.

Наявність у структурі методу case-study суперечок і дискусій, аргументації тренує учасників обговорення, учить дотримання норм і правил спілкування. Викладач закладу вищої освіти повинен бути досить емоційним протягом усього освітнього процесу навчання, дозволяти й не допускати конфрлікти, створювати ситуацію співробітництва й конкуренції одночасно, забезпечувати дотримання особистих прав здобувача. 
Наведемо загальну структуру побудови проблеми та вивчення кейса, що має такий алгоритм проведення:

1) кожна академічна група виконує одну конкретну тему впродовж усіх практичних занять, тому вона $€$, по суті, однією командою, хоча й розбитою на підгрупи; необхідно, щоб кожна підгрупа чітко уявляла, за які рішення вона відповідає перед іншими підгрупами;

2) різні команди (підгрупи) академічної групи, одночасно працюючи над різними темами кейса, конкурують між собою в пошуку найоптимальнішого рішення; зауважимо, що в цьому випадку потрібний значний обсяг аудиторних практичних занять, щоб кожна команда послідовно пройшла всі теми навчального курсу; практика свідчить, що на розробку однієї теми потрібно зазвичай 4 години практичних занять. При пошуку шляхів розв'язання проблемних ситуацій найчастіше використовуються такі інтерактивні методи, як «мозковий штурм», морфологічний аналіз, синектичний аналіз тощо» [5].

Проектуючи такий алгоритм на лабораторне чи практичне заняття з курсу «Основ охорони праці» та «Безпека життєдіяльності», фрормулювання кейса зводиться до постановки проблеми певного виробничого характеру (з чим потенційно може стикнутися майбутній учитель трудового навчання та технологій на робочому місці), повідомлення особливостей офрормлення лабораторно-практичного аналізу й детального опису ситуації викладачем. Крім того, з огляду на специфріку охорони праці, необхідно забезпечити студентів відповідною нормативно-правовою документацією, зміст якої чітко відповідає змісту практичного заняття.

Наведений вибір цих методів не є безпідставним, адже забезпечить високу якість як практичної, так і теоретичної підготовки майбутнього педагога. Проблемно-пошукові, ситуативні принципи організації практичних занять з охорони праці та безпеки життєдіяльності дають змогу забезпечити якісну комплексну підготовку кожного окремого компонента просресійної діяльності вчителя трудового навчання та технології на основі реальних, максимально наближених умов його майбутньої роботи.

Отже, засвоєння освітніх компонентів «Безпека життєдіяльності» й «Основи охорони праці» пропонує не лише сорормувати високий рівень знань профресійної підготовки, а й дати розуміння найвищої цінності людини та людського життя.
Завдання такої підготовки полягає в оволодінні теоретичними знаннями та практичними вміннями й навичками, які необхідні для майбутнього фахівця. Ця форма навчання дасть змогу майбутньому спеціалісту галузі засвоїти навички аналізу різноманітних кризових ситуацій, наочно уявити особливості прийняття рішень у ситуаціях невизначеності, аналізу різних підходів до розробки остаточного дієвого плану дій, навчання приймати самостійне рішення на основі аналізу ситуацій, а також навчитися вміло за допомогою такого аналізу будувати модель виходу з кризових ситуацій.

Висновки. Отже, вивчення освітніх компонентів «Безпека життєдіяльності» й «Основи охорони праці» $€$ необхідною умовою формування програмних результатів навчання здобувача вищої освіти. Зміст цих дисциплін, з огляду на чітку сорормовану структуру, має на меті ознайомити студентів ЗВО з їхніми особистими правами й обов'язками під час наступного працевлаштування та безпосередньо під час виконання своїх профресійних обов'язків. Ці дисципліни залишаються в ракурсі інтересів здобувачів вищої освіти практично всіх без винятку спеціальностей, що підтверджується переліком компетентностей і програмних результатів навчання.

\section{БІБЛІОГРАФІЧНИЙ СПИСОК:}

1. Бєгун В.В., Науменко І.М. Безпека життєдіяльності. Київ : УАНП «Фенікс», 2004. 328 с.

2. Жданова В.Г. Працеохоронна підготовка майбутніх фрахівців з економіки на прикладі нормативної дисципліни «Основи охорони праці». Техногенноекологічна безпека України: стан та перспективи розвитку : матеріали Всеукраїнської наук. практ. конфр. Ірпінь, 2013. С. 122-123.

3. Желібо Є.П., Заверуха Н.М., Зацарний В.В. Безпека життєдіяльності : навчальний посібник / за ред, Є.П. Желібо. 6-е вид. Київ : Каравела, 2008. 344 с.

4. Зоріна М.О. До проблеми визначення актуальності й особливостей формування культури безпеки життєдіяльності. Педагогіка фрормування творчої особистості у вищій і загальноосвітній школах. 2010. C. 149-153.

5. Курач М.С., Ємець О.П. Метод аналізу конкретних ситуацій як педагогічна технологія при вивченні загальнотехнічних дисциплін. Науковий вісник Кременецької обласної гуманітарно-педагогічної академії ім. Тараса Шевченка. Серія «Педагогіка». 2018. Вип. 10. С. 48-58.

6. Охорона праці : навчальний посібник / за ред. В. Кучерявого. Львів : ОріянаНова, 2007. 368 с. 